\title{
Langerhans' cells and subtypes of human papillomavirus in cervical intraepithelial neoplasia
}

\author{
Robert J S Hawthorn, John B Murdoch, Allan B MacLean, Rona M MacKie
}

\begin{abstract}
There is strong circumstantial evidence that human papillomavirus is a cofactor in the development of cervical neoplasia. Systemic immunosuppression has also been implicated. A study was therefore carried out examining the relation between subtypes of human papillomavirus and local immunocompetent cells in the cervix. Colposcopically directed punch biopsy specimens were taken from normal cervix and from histologically proved cervical intraepithelial neoplasia for immunohistochemical studies. Human papillomavirus genome probing was performed on the abnormal specimens. A relation was apparent between decreased Langerhans' cells and moderate to high copy numbers of human papillomavirus type 16. The reduction in Langerhans' cells was significant for human papillomavirus type 18 even at low copy numbers. Conversely, the absence of human papillomavirus was associated with increased numbers of Langerhans' cells in cervical intraepithelial neoplasia.
\end{abstract}

These findings suggest that the proposed oncogenic potential of human papillomavirus type 16 and human papillomavirus type 18 in particular may be mediated by a specific effect on the afferent limb of the immune response.

\section{Introduction}

In the past five years human papillomavirus infection has attracted attention because of the frequency with which it is found in cervical smears and the concern that its presence generates. Some authorities have noted the consistent presence of human papilloma virus types 16 and 18 in both preinvasive and invasive squamous cell cervical cancers and postulated that this virus causes cervical neoplasia. ${ }^{1.4} \mathrm{~A}$ mechanism for such virus induced change is still speculative but may be mediated by immune deficiency including local reduction in the population of Langerhans' cells.' We report the specific relation between reduction in Langerhans' cells and particular subtypes of human papillomavirus.

Lee and Eisinger suggested that cell mediated immunity had the main role in limiting viral infection. Immunosuppression, both exogenous and endogenous, has been associated with viral lesions, and furthermore immunosuppressed women, such as those with renal transplants, are known to be at high risk of neoplastic changes in the squamous epithelium of the skin and lower genital tract. ${ }^{7-9}$ The initial step in the generation of $\mathrm{T}$ cell response to viral infection or tumour is the presentation of antigen to the immune system. This occurs in association with genetically restricted surface antigens on antigen presenting cells to stimulate a $\mathrm{T}$ cell response. ${ }^{10}$ The Langerhans cell is an archetypal antigen presenting cell and appears to be ideally placed for a role in immunosurveillance in squamous epithelium." The full development of such a cell mediated response probably requires contribution from the epithelial cells themselves. It is surface major histocompatibility complex class I antigens on the epithelial cells that are essential for recognition by $T$ cells in the efferent response. ${ }^{1213}$

To investigate the effects of specific subtypes of human papillomavirus on the afferent immune surveillance system we have examined the distribution of Langerhans' cells in cervical intraepithelial neoplasia with and without infection by human papillomavirus types 16 and 18 . We aimed at testing the hypothesis that specific subtypes of human papillomavirus are associated with impaired local immunocompetence and establishing that this may be part of the mechanism through which the oncogenic potential of the virus is mediated.

\section{Patients and methods}

Twenty three patients attending a colposcopy clinic because of abnormal cervical cytology were recruited to the study. Approval had been given by the ethical committee and informed consent was obtained from the patients.

Paired biopsy specimens of normal ectocervix and abnormal transformation zone were taken under colposcopic control from each patient. Separate biopsy forceps were used to avoid cross contamination. Immunohistochemical studies were performed on both specimens and human papillomavirus gene probing on the abnormal specimens. A biopsy specimen taken for routine diagnosis was available for comparison.

\section{IMMUNOHISTOCHEMICAL STUDIES}

Optimal freezing and orientation of specimens was by the method of Fletcher $e t a l .{ }^{14}$ Both the normal and abnormal specimens were processed simultaneously. Every fifth section was stained with haematoxylin and eosin to confirm the histological diagnosis. Immunohistochemical staining was performed within one week of collection.

Langerhans' cells were identified by an indirect immunoperoxidase method modified from that reported by MacKie and Turbitt ${ }^{15}$ using a mouse monoclonal antibody to $\mathrm{T} 6(\mathrm{CDl})$ antigen $(\mathrm{NAl} / 34$; SERA-LAB). Major histocompatibility complex class I (W6/32; SERA-LAB) and class II (DA6/231; MRC Edinburgh) antigen staining were also examined. Sections were counterstained with blued haematoxylin, dehydrated, and mounted in Histomount for microscopy.

The distribution and morphological detail of the Langerhans' cells were recorded for both the normal and abnormal specimens in each case. Definite Langerhans' cell bodies were counted per 100 basal cells in each biopsy specimen with use of an Olympus BHS 312 microscope at 250 times magnification. 
DNA-DNA HYBRIDISATION

Human papillomavirus type 16 DNA cloned into the BamH1 site of pBR322 and human papillomavirus type 18 cloned into the ECORI site of pBR322 were used in the DNA-DNA hybridisation studies. Human papillomavirus DNA was released from the vectors by the appropriate restriction endonuclease digestion and purified twice by electroelution after agarose gel electrophoresis.

Biopsy specimens stored at $-20^{\circ} \mathrm{C}$ were chopped finely with a sterile blade and the DNA extracted in $0.4 \%$ sodium dodecyl sulphate, $0.1 \mathrm{M}$ sodium chloride, $0.01 \mathrm{M}$ edetic acid (disodium salt), $0.05 \mathrm{M}$ trometamol (TRIS) hydrochloric acid $\mathrm{pH} 8 \cdot 0$, and proteinase $\mathrm{K}$ (Boehringer) $200 \mathrm{mg} / \mathrm{l}$. The sample DNA was then extracted with phenol and chloroform before ethanol precipitation. Thereafter, the samples were treated with ribonuclease A $100 \mathrm{mg} / \mathrm{l}$. Sample DNA was quantified against a known standard lambda DNA (Gibco; Paisley, Scotland).

Three micrograms of each sample together with appropriate human papillomavirus reconstructions containing equivalent amounts of mammalian DNA were transferred through a Minifold 11 slot blot apparatus (Schleicher and Schuell) on to the reprobable nylon membrane Genescreen Plus (New England Nuclear), which had been presoaked in $10 \times$ SCC $(1 \times \mathrm{SCC}$ is $0.15 \mathrm{M}$ sodium chloride and $0.015 \mathrm{M}$ sodium citrate). The membrane was then treated with a

TABLE I-Details of patients and results

\begin{tabular}{|c|c|c|c|c|c|c|}
\hline \multirow{2}{*}{$\begin{array}{l}\text { Case } \\
\text { No }\end{array}$} & \multirow{2}{*}{$\begin{array}{c}\text { Age } \\
\text { (years) }\end{array}$} & \multicolumn{2}{|c|}{ Human papillomavirus genome copies/cell } & \multicolumn{3}{|c|}{ Langerhans' cells/100 basal cells } \\
\hline & & Type 16 & Type 18 & Normal biopsy tissue & & Abnormal biopsy tissue \\
\hline 1 & 34 & 1 & 0 & 7 & & 15 \\
\hline 2 & 31 & 1 & 0 & 4 & & 15 \\
\hline 3 & 26 & 1 & 0 & 8 & & 4 \\
\hline 4 & 25 & i & 0 & 11 & & 5 \\
\hline 5 & 31 & 0 & 0 & 10 & & 13 \\
\hline 6 & 27 & 0 & 0 & 6 & & 9 \\
\hline 7 & 40 & 0 & 0 & 6 & & 10 \\
\hline 8 & 29 & 0 & 1 & 11 & & 5 \\
\hline 9 & 28 & 0 & 2 & 14 & & 10 \\
\hline 10 & 19 & 1 & 0 & 6 & & 6 \\
\hline 11 & 26 & 0 & 1 & 6 & & 4 \\
\hline 12 & 33 & 0 & $2+$ & 12 & & 7 \\
\hline 13 & 29 & 0 & 2 & 12 & & 6 \\
\hline 14 & 23 & 0 & 1 & 14 & . & 11 \\
\hline 15 & 36 & 0 & 1 & 7 & & 5 \\
\hline 16 & 34 & 0 & 0 & 11 & & 21 \\
\hline 17 & 24 & 0 & 1 & 8 & & 5 \\
\hline 18 & 27 & 2 & 0 & 7 & & 5 \\
\hline 19 & 33 & 0 & 0 & 11 & & 14 \\
\hline 20 & 32 & 2 & 0 & 5 & & 4 \\
\hline 21 & 30 & 0 & 0 & 9 & & 8 \\
\hline 22 & 35 & 1 & 0 & 9 & & 12 \\
\hline 23 & 37 & 2 & 0 & 10 & & 6 \\
\hline
\end{tabular}

^Human papillomavirus copies/cell: $0=<10,1=10-50,2=51-100,2 \dagger=>100$ denaturing solution containing $0 \cdot 4 \mathrm{M}$ sodium hydroxide and $0.6 \mathrm{M}$ sodium chloride for 20 minutes and transferred to a neutralising solution containing $0.5 \mathrm{M}$ trometamol $\mathrm{pH} 7 \cdot 0$ and $1 \mathrm{M}$ sodium chloride for 20 minutes before drying at $37^{\circ} \mathrm{C}$ for 40 minutes.

Purified probes were radiolabelled with $\alpha$ phosphorus-32-deoxyadenosine triphosphate and $\alpha$-phosphorus-32-deoxythymidine triphosphate to a specific activity in excess of $1 \times 10^{8}$ counts $/ \mathrm{min} / \mu \mathrm{g}$ DNA. The membrane was prehybridised at $42^{\circ} \mathrm{C}$ in $50 \%$ formamide (Fluka), 10\% dextran sulphate, $1 \%$ sodium dodecyl sulphate, and $1 \mathrm{M}$ sodium chloride for 30 minutes. The probes plus denatured salmon sperm DNA (Sigma) $100 \mathrm{mg} / 1$ and $0.5 \mu \mathrm{g}$ cold denatured pBR322 were treated with $1 M$ sodium hydroxide for 20 minutes at room temperature before neutralising with $1 \mathrm{M}$ hydrochloric acid. This solution was then added to the prehybridisation mix and the samples hybridised at $42^{\circ} \mathrm{C}$ for 18 hours. Cold pBR322 was added to block hybridisation of any residual radiolabelled pBR322 in the purified probe to the sample DNA. Thereafter, the membrane was washed in $2 \times \mathrm{SCC}$ and $0.1 \%$ sodium dodecyl sulphate at $68^{\circ} \mathrm{C}$ (stringent conditions) and autoradiographed with use of intensifying screens on X-Omat film (Kodak).

\section{Results}

Table I shows the human papillomavirus copy numbers per cell and numbers of Langerhans' cells from the normal and abnormal biopsy specimens. The level of genome expression was based on densitometry compared with known copy number reconstructions. Under 10 copies of human papillomavirus DNA per cell was taken as a negative result. ${ }^{16}$ Low, moderate, and high levels of expression were taken to represent $10-50,51-100$, and over 100 copies per cell respectively. Most human papillomavirus DNA positive lesions (11/ 17) showed low levels of genome expression (table I).

Groups were defined according to the presence and level of human papillomavirus types 16 and 18 genome copies per cell. Statistical analysis was performed on the difference (normal-abnormal) and percentage difference $($ (normal-abnormal/normal $) \times 100)$ in Langerhans' cells in the paired biopsy specimens. The median difference and percentage differences were expressed with $95 \%$ confidence intervals. Nonparametric testing was also performed by means of the Wilcoxon matched pairs signed ranks test.

Human papillomavirus type 18 with over 10 copies per cell was significantly associated with decreased numbers of Langerhans' cells (tables II and III). Table I suggests that human papillomavirus type 16 in

TABLE II-Human papillomavirus types 16 and 18, copy numbers/cell, and cervical Langerhans' cells

\begin{tabular}{|c|c|c|c|c|c|c|}
\hline \multirow{2}{*}{ 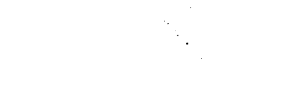 } & \multirow{2}{*}{$\begin{array}{c}\text { Copy } \\
\text { Nos/cell }\end{array}$} & \multirow{2}{*}{$\begin{array}{l}\text { No of } \\
\text { cases }\end{array}$} & \multirow[b]{2}{*}{ Median } & \multirow{2}{*}{$\begin{array}{l}\text { Wilcoxon paired } \\
\text { signed ranks test }\end{array}$} & \multicolumn{2}{|c|}{$95 \%$ Confidence interval } \\
\hline & & & & & $\%$ (Normal-abnormal/normal) & No (normal-abnormal) \\
\hline Human papillomavirus type 16 & $10-50$ & 6 & $\left\{\begin{array}{r}-2 \cdot 0 \\
-32 \cdot 1\end{array}\right.$ & $\begin{array}{l}p>0.05 \\
p>0.05\end{array}$ & $-194 \cdot 6$ to $52 \cdot 3$ & $-9 \cdot 5$ to $5 \cdot 0$ \\
\hline Human papillomavirus type 18 & $10-50$ & 5 & $\left\{\begin{array}{r}3 \cdot 0 \\
33 \cdot 3\end{array}\right.$ & $\begin{array}{l}p=0.031 \\
p=0.031\end{array}$ & $21 \cdot 4$ to $54 \cdot 6$ & $2 \cdot 0$ to $6 \cdot 0$ \\
\hline
\end{tabular}

TABLE III-Human papillomavirus types 16 and 18 positive and negative biopsy specimens in relation to cervical Langerhans' cells

\begin{tabular}{|c|c|c|c|c|c|}
\hline & \multirow{2}{*}{$\begin{array}{l}\text { No of } \\
\text { cases }\end{array}$} & \multirow[b]{2}{*}{ Median } & \multirow{2}{*}{$\begin{array}{l}\text { Wilcoxon paired } \\
\text { signed ranks test }\end{array}$} & \multicolumn{2}{|c|}{ 95\% Confidence interval } \\
\hline & & & & $\%($ Normal-abnormal/normal $)$ & No (normal-abnormal) \\
\hline Human papillomavirus type 16 positive & 9 & $\begin{array}{l}0.5 \\
3.3\end{array}$ & $\begin{array}{l}p>0.05 \\
p>0.05\end{array}$ & $-123 \cdot 2$ to $41 \cdot 6$ & $-5 \cdot 5$ to $4 \cdot 0$ \\
\hline Human papillomavirus type 18 positive & 8 & $\left\{\begin{array}{r}4 \cdot 0 \\
36 \cdot 6\end{array}\right.$ & $\begin{array}{l}p=0.007 \\
p=0.007\end{array}$ & $27 \cdot 4$ to $48 \cdot 1$ & 2.5 to 5.5 \\
\hline No human papillomavirus & 6 & $\left\{\begin{array}{r}-3 \cdot 0 \\
-40 \cdot 0\end{array}\right.$ & $\begin{array}{l}p=0.03 \\
p=0.03\end{array}$ & $78 \cdot 9$ to $-8 \cdot 1$ & $-7 \cdot 0$ to $-1 \cdot 0$ \\
\hline
\end{tabular}


higher copy numbers per cell $(>50)$ may be producing a similar effect (positive differences in all cases), though the numbers of observations were too small for valid analysis.

Any correlation between copies of human papillomavirus type 18 genome per cell and reduction in Langerhans' cells was difficult to evaluate because of the small number of specimens with over 50 copies of viral genome per cell.

A significant increase in Langerhans' cell numbers was detected in specimens with no evidence of virus when the normal internal control was compared with the abnormal biopsy specimen (table III).

The age range was 19-37 in patients with human papillomavirus type $16,23-36$ in those with human papillomavirus type 18 , and $27-40$ in the absence of viral genomes.

The morphology of Langerhans' cells was altered in both the biopsy specimens showing combined lesions and those containing pure cervical intraepithelial neoplasia. The main change occurred to the dendrites, which became stunted. Cell bodies appeared unaltered (figs one and two).

\section{Discussion}

DNA-DNA hybridisation is the most sensitive and specific way of detecting human papillomavirus. We have found that the correlation among histological diagnosis, positive staining for papillomavirus antigen, and DNA-DNA hybridisation to human papillomavirus subtypes is poor. ${ }^{17}$ We have also shown that slot blot analysis offers low specificity if human papillomavirus DNA is present at low copy number. ${ }^{16}$ At higher copy numbers (over 10 copies per cell), however, it is both sensitive and specific. It is not possible with this technique to differentiate between combined human papillomavirus type 16 and type 18 infection.

A previous study on Langerhans' cells in cervical intraepithelial neoplasia found an apparent decrease in numbers in lesions with histological evidence of human papillomavirus infection. ${ }^{5}$ An increased density was reported in cervical tissue with intraepithelial neoplasia only.$^{18-20}$ No other study has compared directly Langerhans' cell numbers in normal ectocervical epithelium with areas of intraepithelial neoplasia in the

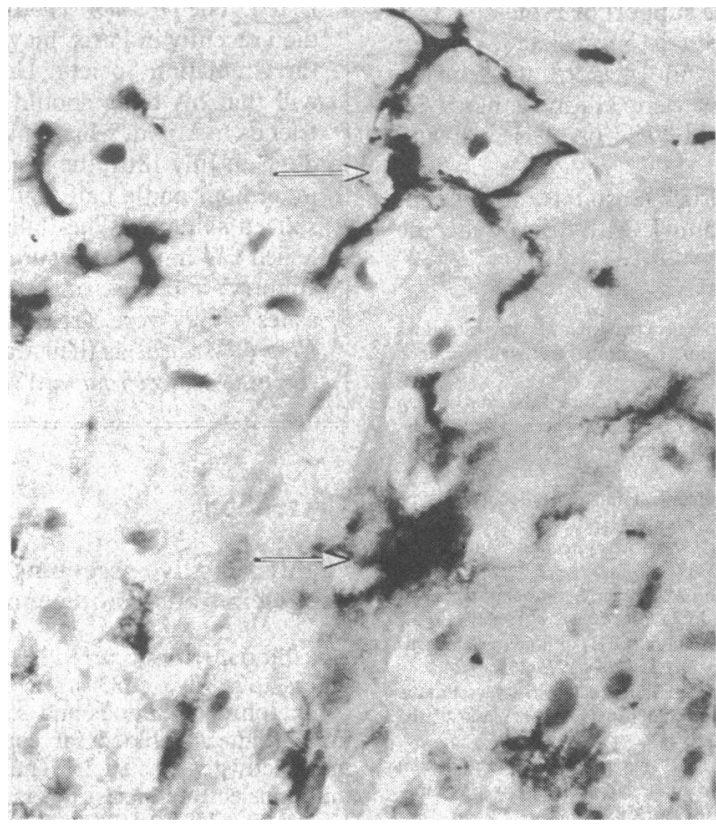

FIG 1-Langerhans' cells in normal cervical epithelium. Cell bodies arrowed; dendrites shown best higher in the epithelium. (NAI/34 $(S E R A-L A B) \times 40$ objective and interference phase contrast enhancement)

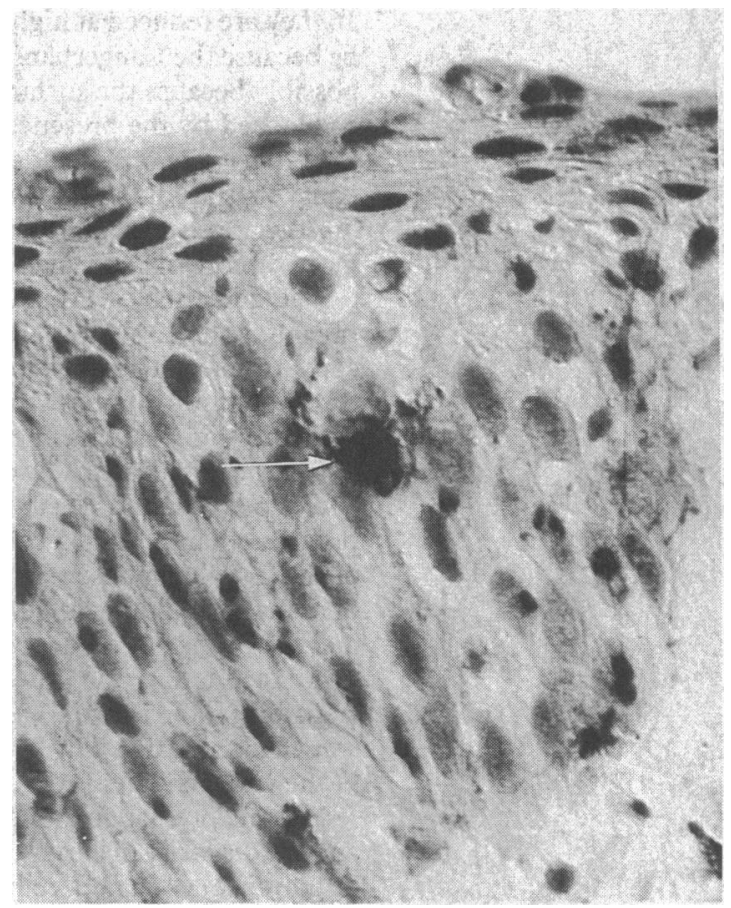

FIG 2-Langerhans' cells in abnormal cervical epithelium. Cell body with stunted dendrites arrowed. (NA1/34 (SERA-LAB) $\times 40$ objective and interference phase contrast enhancement)

same cervix. This comparison appears to be important, as the variation in the normal and abnormal cervix in reported series is up to 100 -fold. ${ }^{21} \mathrm{We}^{22}$ and others have recorded similar numbers of Langerhans' cells in ectocervix and the transformation zone, ${ }^{2324}$ so that number of Langerhans' cells in the ectocervix appears to represent a valid internal control.

Staining for surface T6 (CD1) antigen on Langerhans' cells with use of NAl/34 (human thymocyte antigen) is one of the most sensitive methods of their detection in squamous epithelium. Some workers ${ }^{521}$ evidently favour $\mathrm{S} 100$ as a marker despite the fact that it detects only $35 \%$ of Langerhans' cells. ${ }^{5}$ Tay et al suggest functional importance for $\mathrm{S} 100$ positive cells. Nevertheless, the only recognised functional markers are surface major histocompatibility class II antigens, necessary for the antigen presentation to helper $T$ cells. Our results confirm observations of others that these surface antigens are frequently expressed on the dysplastic epithelial cells themselves. ${ }^{1825}$

Epithelial cells have recently been shown to be capable of class II antigen synthesis in response to production of $\gamma$ interferon. ${ }^{26}$ They may thus be acting as antigen presenting cells in their own right, augmenting the immune response in addition to their role in facilitating $T$ cell maturity in the so called "cervical associated lymphoid tissue" analogous to their role in skin. ${ }^{27}$ Experimental evidence also points to the possibility that class II antigens may be recognition sites for the efferent $T$ cell response.$^{28}$ Hence surface antigen changes on the epithelial cells may be strongly influencing the local detection of neoantigens. Our findings also show that the more classical cytotoxic $T$ cell recognition sites (class I antigens) tend to be increased in all types of cervical dysplasia. Loss of these antigens has been implicated in some tumours associated with a viral cause in animals. ${ }^{29}$ This would tend to imply that if a defect in the local immune response has a contributory role in the generation and progression of cervical intraepithelial neoplasia this defect is more likely to be in the afferent limb of the response.

Our results show that Langerhans' cells are significantly decreased in cervical neoplasia in the presence of human papillomavirus type 18 even in low copy number. In the presence of human papillomavirus type 
16 they are reduced at higher copy numbers. This may be because the Langerhans' cells are truly decreased or possibly because the surface antigens are being altered or blocked by the presence of human papillomavirus. Other explanations include the possibility that Langerhans' cells are inhibited from passing into the epithelium or are encouraged to migrate from the epithelium more rapidly than normal.

The depletion of Langerhans' cells may be a function of both subtype of human papillomavirus and copy number. The question whether there is a critical threshold copy number cannot be answered by slot blot hybridisation, as this method does not distinguish between samples with low copy number (fewer than 10 copies per cell) and negative samples. It may be that a progressive immunological failure on the afferent limb of the $T$ cell response results from increased presence of human papillomavirus. Alternatively local immunodeficiency may precede human papillomavirus infection, facilitating the infection and subsequent cell transformation by viral gene products..$^{30}$ No attempt was made in this study to detect possible integration of the viral genome.

Not all premalignant lesions progress to invasion and the disparity in local response may be of prognostic importance, impaired cellular immunity resulting in failure of the local immune response, tolerance to the neoantigens, and subsequently carcinoma. Any moderating effect of antigen presentation by epithelial cells when Langerhans' cells are decreased is difficult to evaluate but may be one explanation why only a minority of these lesions progress to invasive carcinoma.

The presence of preinvasive lesions which do not manifest human papillomavirus genomes suggests that human papillomavirus is not likely to be the sole agent in cervical neoplasia and many cofactors are implicated. They may not all include depletion of Langerhans' cells, but preliminary results in high risk, immunosuppressed renal allograft recipients also show signifcantly reduced Langerhans' cells in colposcopically and histologically normal cervix and may be one explanation why this group is at increased risk of cervical neoplasia.

We thank Dr J W Cordiner, Dr J MacNab, Dr I More, Dr $\mathrm{R}$ Burnet, and $\mathrm{Mr} \mathrm{T}$ Aitchison for helpful advice in the preparation of this paper. Thanks are also due to $\mathrm{Dr} M$ Turbitt and $\mathrm{Mr}$ W Thomson. The support of Professors C R Whitfield and R N M MacSween is appreciated. Cloned human papillomavirus types 16 and 18 DNA used in the DNA-DNA hybridisation studies were kindly donated by Professor Harald zur Hausen and Dr Lutz Gissman and colleagues.

RJSH was supported by the Scottish Hospitals Endowment Research Trust (grant No 697), and JBM by the Wellcome Trust.

1 zur Hausen $\mathrm{H}$. Human genital cancer: synergism between two virus infection or synergism between a virus infection and initiating events? Lance 1982 ;ii: $1370-2$.

2 Gissman L, Wolnik L, Ikenberg H, Koldovsky U, Schnurch HG, zur Hausen H. Human papillomavirus types 6 and 11 DNA sequences in genital and laryngeal papillomas and in some cervical cancers. Proc Natl Acad Sci USA 1983;80:560-3.

3 Crum CP, Ikenberg H, Richart RM, Gissman L. Human papillomavirus type 16 and early cervical neoplasia. $N$ Engl 7 Med 1984;310:880-3.

4 Singer A, Walker P, McCance DJ. Genital wart virus infections: nuisance or potentially lethal? Br Med $\mathcal{F} 1984 ; 288: 735-7$.

5 Tay SK, Jenkins D, Maddox P, Campion M, Singer A. Subpopulations of Langerhans' cells in cervical neoplasia. Br f Obstet Gynaecol 1987;94:10-5.

6 Lee AKY, Eisinger M. Cell mediated immunity (CMI) to human wart virus and wart associated tissue antigens. Clin Exp Immunol 1976;26:419:24.

7 Schneider V, Kay S, Lee HM. Immunosuppression as a high-risk factor in the development of condyloma acuminatum and squamous neoplasia of the development of condyloma acuminatum and
cervix. Acta Cytol (Baltimore) 1983;27:220-4.

8 Sillman F, Stanek A, Sedlis A, et al. The relationship between human papillomavirus and lower genital intraepithelial neoplasia in immunosuppressed women. Am J Obstet Gynecol 1984;150:300-8.

9 Penn I. Cancers of the anogenital region in renal allograft recipients. Cance 1986;58:611-6.

10 Braathen LR, Bjercke S, Thorsby E. The antigen presenting function of human Langerhans cells. Immunobiology 1984;168:301-12.

11 Rowden G. The Langerhans cell. CRC Crit Rev Immunol 1981;3:95-180.
12 Gaston JSH, Waer $M$. Virus-specific MHC-restricted T lymphocytes may initiate allograft rejection. Immunology Todoy 1985;6:237-9.

13 Lew AM, Lillehoi EP, Cowan EP, Maloy WL, Van Schravendijk MR Colligan JE. Class I genes and molecules: an update. Immunolog 1986;57:3-18.

14 Fletcher S, Smart GE, Livingstone JRB. Grading of cervical dysplasias by frozen section. Lancet 1985;ii:559-60.

15 MacKie RM, Turbitt ML. Quantitation of dendritic cells in normal and abnormal human epidermis using monoclonal antibodies directed against I and HTA antigens. $\mathcal{f}$ Invest Dermatol 1983;81:216-20.

16 Murdoch JB, Cordiner JW, Macnab JCM. Relevance of HPV-16 to laser therapy for cervical lesions. Lancet $1987 ; \mathrm{i}: 1432$.

17 Murdoch JB, Cassidy LJ, Fletcher K, Cordiner JW, Macnab JCM. Histological and cytological evidence of viral infection and human papillomavirus type 16 DNA sequences in cervical intraepithelial neoplasia and normal tissue in the west of Scotland: evaluation of treatment policy. Br Med $\mathcal{J}$ tissue in the west

18 Morris HHB, Gatter KC, Sykes G, Casemore V, Mason DY. Langerhans' cells in human cervical epithelium: effects of wart virus infection and intraepiin human cervical epithelium: effects of wart virus infect

19 MacLean AB. Cervical healing and Langerhans' cells. Br $\mathcal{J}$ Obstet Gynaecol 1984;91:1145-8.

20 Caorsi I, Figueroa CD. Langerhans' cell density in the normal exocervical epithelium and in the cervical intraepithelial neoplasia. Brf Obstet Gynaecol 1986;93:993-8.

21 McArdle JP, Muller HK. Quantitative assessment of Langerhans' cells in human cervical intraepithelial neoplasia and wart virus infection. $A m \mathcal{J}$ Obstet Gynecol 1986;154:509-15.

22 Hawthorn RJS, MacLean AB. Langerhans' cell density in the normal exocervical epithelium and in the cervical intraepithelial neoplasia. $\mathrm{Br} \mathcal{J}$ Obstet Gynaecol 1987;94:815-6.

23 Morris HHB, Gatter KC, Stein H, Mason DY. Langerhans' cells in human cervical epithelium. Br f Obstet Gynaecol 1983;90:400-11.

24 Edwards JNT, Morris HB. Langerhans' cells and lymphocyte subsets in the female genital tract. Br 7 Obstet Gynaecol 1985;92:974-82.

25 Morris HB, Gatter KC, Pulford K, et al. Cervical wart virus infection, intraepithelial neoplasia and carcinoma; an immunohistological study using a panel of monoclonal antibodies. Br F Obstet Gynaecol 1983;90:1069-81.

26 Wikner NE, Huff JC, Norris DA, et al. Study of HLA-DR synthesis in cultured human keratinocytes. I Invest Dermatol 1986;87:559-64.

27 Barclay N, Mason DY. Induction of Ia antigen in rat epidermal cells and gut epithelium by immunological stimuli. 7 Exp Med 1982;156:1665-76.

28 Breathnach SM, Katz SI. Cell mediated immunity in cutaneous disease. Hum Pathol 1986;17:161-7.

29 Festenstein H, Garrido F. MHC antigens and malignancy. Nature 1986;322:502-3.

30 Schneider-Gadicke A, Schwarz. E. Different human cervical carcinoma cell lines show similar transcription patterns of human papillomavirus type 18 early genes. EMBO f 1986;5:2285-92.

(Accepted 3 fune 1988)

\section{ONE HUNDRED YEARS AGO}

The proposed reform of the burial laws in France not having yet been carried into effect, cremation is still illegal in that country. Under these circumstances, bodies which it is desired to cremate have to be taken to Italy for the purpose. The Italian Custom House appears to have discovered in this necessity a source of revenue which it was advisable to make the most of while it lasted. The post-mortem adventures of a M. Morin, who died recently in Paris, may be of interest to members of the Cremation Society. He had left instructions in his will that his body should be conveyed by two of his friends to Milan, where it was to be cremated. This was done on July 18th, the incineration being accomplished in an hour and a half, and costing between fifteen and sixteen shillings. The Italian Custom House, however, levied $\$ 14$ import duty on the body when it entered the country, and the same amount as export duty on the ashes as they were carried back to France. This (says the Progrès Médical) is their way of encouraging cremation! (British Medical fournal 1888;ii:503)

\section{Correction}

Highly sensitive screening tests for hepatitis B surface antigen in transfusion centres of developing countries

An editorial error occurred in this paper by Dr Vaskar Saha and others (30 July, $p$ 334). In the first sentence of the fourth paragraph of "Methods and results" the cost of detecting each unit of infected blood for counterimmunoelectrophoresis was incorrectly given as $\$ 6.25$. The sentence should read, "Counterimmuncelectrophoresis, reverse passive haemagglutination, and ELISA cost US $\$ 0.50, \$ 1.00$, and $\$ 2.00$ respectively per unit, so that detecting each unit of infected blood would cost $\$ 62.50$ $(\$ 0.50 \div 0.8 \%)$ for counterimmunoelectrophoresis, $\$ 45.50$ $(\$ 1.00 \div 2 \cdot 2 \%)$ with reverse passive haemagglutination, and $\$ 28.60(\$ 2.00 \div 7 \%)$ with ELISA." 